DOI: 10.17746/1563-0110.2019.47.4.077-084

A.P. Borodovsky' and A.Y. Trufanov
${ }^{1}$ Institute of Archaeology and Ethnography,
Siberian Branch, Russian Academy of Sciences,
${ }^{2}$ Research and Analytical Center of Cultural and Natural Heritage Preservation Problems "AVKOM-Heritage",
Tokarey 24A, Yekaterinburg, 620028, Russia
E-mail: trufanov_alex@rambler.ru

\title{
Ceramic Protomes of Horses from Late Bronze to Early Iron Age Sites in the Southern Taiga Zone of Siberia
}

This study introduces ceramic protomes of horses from the southern taiga zone of Siberia: specifically, from the Middle Irtysh region (Novotroitskoye I) and the Angara region (Strelkovskoye-2). These artifacts are part of a crosscultural phenomenon. The analysis of their decorative elements suggests that they represent bridles. Close resemblance to Assyrian reliefs showing bridled horses makes it possible to identify the main details of Middle Eastern horse trappings, such as a bridle, a head-rope, and a breast-collar. Also, Siberian specimens display indirect parallels to the archaic classic tradition of using horse protomes in ritual ceremonies. The most important factor behind the appearance of ceramic horse protomes in the southern taiga zone of Siberia was the adoption of horse-breeding and eventually horse-riding, as evidenced by Late Bronze to Early Iron Age bits, cheek-pieces, and parts of harness from the same region. In the early first millennium $B C$, horse protomes become a common iconographic marker throughout Eurasia. They were a typical feature of Early Iron Age art, a prestigious symbol widely used in rituals, possibly associated with bronze casting.

Keywords: Late Bronze Age, Early Iron Age, transition, southern taiga zone, Siberia, protomes, ritual items, animal style.

\section{Introduction}

In the Late Bronze to Early Iron Ages in Eurasia, protomes were commonly used as artistic elements of figurative decoration on various items, including rhytons, furniture, various jewelry, elements of weaponry (handles, pommels, crossbars), and sculptural adornment of architectural details (columns). Protomes were widespread in ancient Eastern (Persian) and Greek art from the 7th-6th to the 3rd-2nd centuries BC.

Long use of protomes in the first millennium BC as one of the most expressive details of decoration on various items and structures was one of the factors of their spread over a vast territory, including Central Asia and Siberia. Among such artifacts from these regions, noteworthy are quite numerous "horse-headed" stone staffs of the Bronze Age, as well as isolated metal socketed pommels from various regions of Kazakhstan, Urals, and the forest-steppe region of the southwestern Siberia (Kovtun, 2012: 96, fig. 1; Molodin, 2014: 87, fig. 1, 2). In the material evidence of the Early Iron Age, items in the form of horse heads occur among the horn artifacts (Arzhan-1, Berezovka, Kyzyl-kul) from Central Asia and isolated bronze pommels from

\footnotetext{
Archaeology, Ethnology \& Anthropology of Eurasia 47/4 (2019) 77-84 E-mail: Eurasia@archaeology.nsc.ru (C) 2019 Siberian Branch of the Russian Academy of Sciences

(C) 2019 Institute of Archaeology and Ethnography of the Siberian Branch of the Russian Academy of Sciences
} (C) 2019 A.P. Borodovsky, A.Y. Trufanov 
Ciscaucasia (Kantorovich, 2016). Ceramic protomes of the Late Bronze to Early Iron Ages from the southern taiga zone of Siberia, including the Middle Irtysh region (Novotroitskoye I) and Lower Angara region (Strelkovskoye-2) stand out among these items.

\section{Material and methods}

One of ceramic horse-shaped protomes comes from the Omsk Region. This artifact was discovered in the settlement of Novotroitskoye I, belonging to the Krasnoozerka culture, which existed in the transition period from the Late Bronze to the Early Iron Ages. The site is located $40 \mathrm{~km}$ north of the city of Omsk, on the terrace of the right bank of the Irtysh River (Fig. 1, 1). This settlement was investigated by A.Y. Trufanov in 1980 1982 and 1984. The habitation time of Novotroitskoye I was quite reliably established by the parallels with the Krasnoozerka evidence from Chicha-1 dated by the radiocarbon method. For example, the date of $2336 \mathrm{BP}$ was obtained for dwelling 10 (zone IVa; excavation 10) where the Krasnoozerka pottery was predominant (84\%). Judging by the calibrated values of that date, V.I. Molodin dated the dwelling to the 9th century BC (2008: 163; Molodin, Parzinger, 2009: 72). According to J. Schneewei $\beta$, it was abandoned closer to the end of the 10 th century $\mathrm{BC}$, but not later than the third quarter of the 9th century BC (2007: 34). Notably, the appearance of the Krasnoozerka pottery from dwelling 10 corresponds to the part of dishware from Novotroitskoye I that suggests a relatively late age for the site in the series of the dynamically developing Krasnoozerka antiquities in the forest-steppe Irtysh region (Abramova, Stefanov, 1985: $121,122)$. The dating of Novotroitskoye I is confirmed by two bronze double-bladed arrowheads found in the settlement: an asymmetric-rhombic one with a hidden socket and a stud (Fig. 2, 1), and a long-socketed one of the Novocherkassk type (Fig. 2, 2), as well as by a cheek-piece with a mushroom-shaped head and three holes in the same plane (Fig. 2,3). Considering that the first arrowhead and cheek-piece belong to the ArzhanChernogorovo antiquities, and the second arrowhead belongs to the Novocherkassk antiquities, and taking into account the radiocarbon dates of Arzhan-1 (Evraziya..., 2005: 97, 98), the site can be dated to the late 9th to early 8 th century BC.

At the Novotroitskoye I settlement, four dwellings and the extensive space between them have been excavated over a total area of $1170 \mathrm{~m}^{2}$. A ceramic horse protome was found in the pit of dwelling 2 , which was investigated in 1981 (see Fig. 1, 2). The area of the dwelling structure was about $80 \mathrm{~m}^{2}$; the depth of the pit from the level of subsoil was $0.2 \mathrm{~m}$. The entrance to the dwelling was not clearly visible. Judging by the planigraphy of the finds and the "gap" in the line of holes from the posts, the

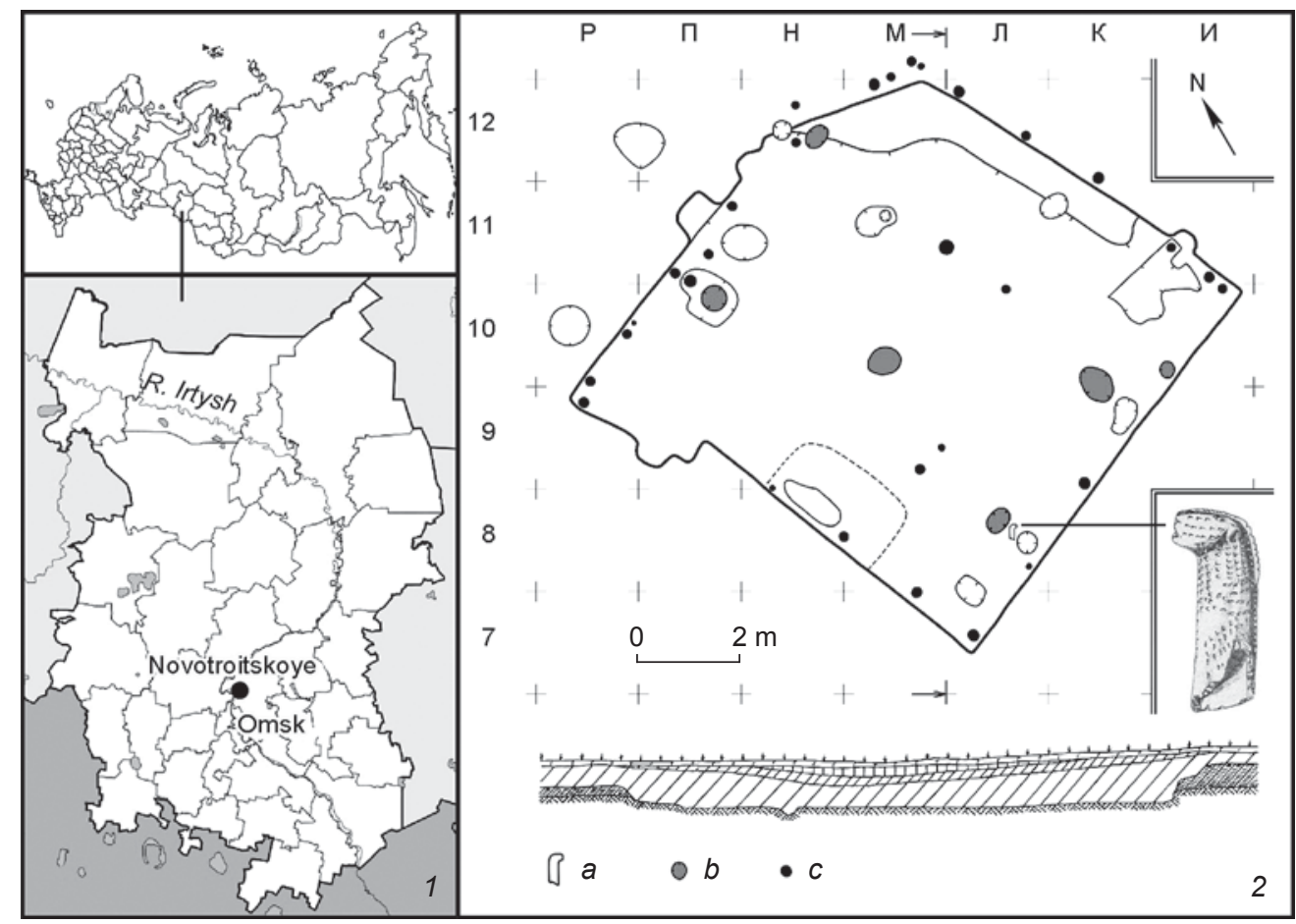

Fig. 1. Location of the Novotroitskoye I settlement (1) and plan of the dwelling where the ceramic protome was discovered (2).

$a$ - protome; $b$ - spot of burnt soil (fireplace); $c$ - hole from a post. 
entrance was likely located in the western wall near the northwestern corner. The ceramic protome was discovered at the southern wall of the pit, closest to the southwestern corner, between the oval fireplace $(50 \times 40 \times 15 \mathrm{~cm})$ and a large vessel dug into the ground. The protome lay $10 \mathrm{~cm}$ above the subsoil level. The height of the item is $19 \mathrm{~cm}$ (Fig. 3, 1); its width is different in different areas, measuring $62 \mathrm{~mm}$ at the base, $57 \mathrm{~mm}$ at the lower end of the mane, and $53 \mathrm{~mm}$ at the level of the ears. The artifact is hollow. The outer diameter at the upper opening of the protome (mouth) is about $43 \mathrm{~mm}$; the inner diameter is about $30 \mathrm{~mm}$. The wall thickness at the base of the neck ranges from $8.3 \mathrm{~mm}$ in the front to $12.8 \mathrm{~mm}$ in the back; near the edge of the muzzle, it measures $5.1 \mathrm{~mm}$ in the lower (neck) part, and $7.8 \mathrm{~mm}$ in the upper part. Holes for the ears and eyes were apparently made with the same tool $3.5 \mathrm{~mm}$ in diameter (Fig. 3, 2). Since various types of archaic representations have long been used as a reliable source on the exterior appearance of ancient horses (Kovalevskaya, 1977: 132), we should give a fairly detailed description of the protome from Novotroitskoye I. The head of the horse is represented markedly short relative to the neck; it looks heavy, and has rounded outlines. The ears are small and pointed, but were quite prominently emphasized in relief. The neck is too long, compared to the natural proportions of a real horse. The mane is rendered by a low notched ridge (Fig. 3, 2), which may correspond both to natural features of horses of the Central Asian origin, and to a special short "brush-like" haircut or a plait made in the upper part of the mane. The latter variety of horse mane design occurs in various Assyrian reliefs (Fig. 4, 3, 4). It is also possible that the notched ridge, extending to the frontal part of the head, represents a long headband typical of the Early Iron Age. As a part of our interpretation, we should mention the shape of the ears on the protome, which is quite consistent with the Scythian-Siberian artistic tradition.

The ornamental decor on the ceramic protome from Novotroitskoye I may be divided into several bands. The first band is on the muzzle of the protome; the second is on the neck; and at least three more neck bands can be distinguished. One band of imprints in the lower part of the neck zone is located in the perpendicular direction, and another one is inclined relative to other bands. These various parts of the decoration can be correlated with the elements of horse trappings. For instance, several lines of imprints along the head from the muzzle to an ear may correspond to the bridle; two bands of imprints on the neck, perpendicular to

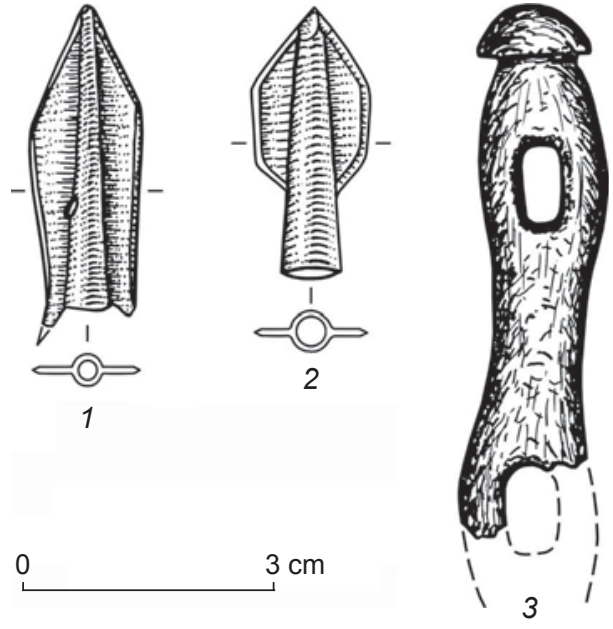

Fig. 2. Dating items from Novotroitskoye I.

1 - bronze arrowhead with a stud; 2 - bronze long-socketed arrowhead; 3 - fragment of a three-hole cheek-piece made of horn.
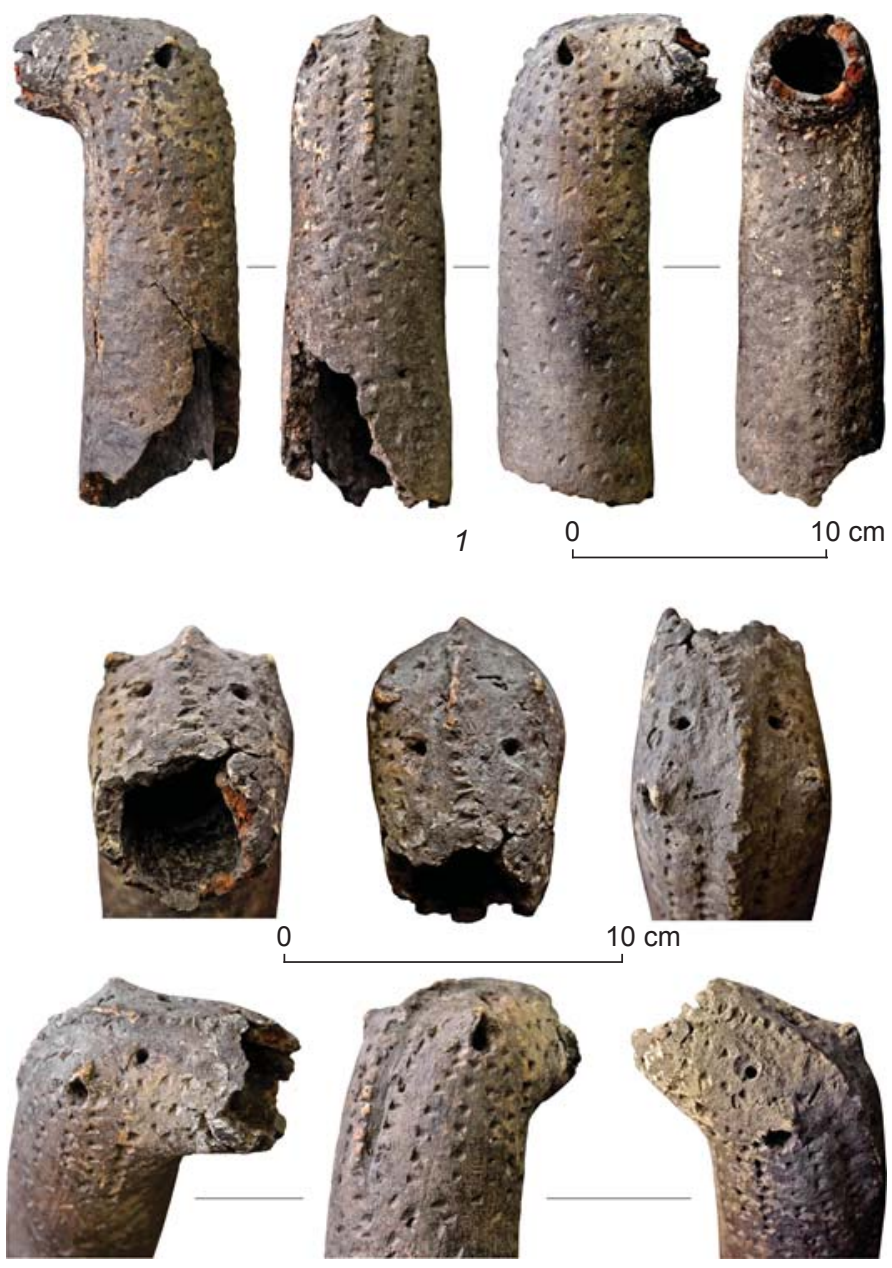

2

Fig. 3. Ceramic protome from Novotroitskoye I. Photo by A.Y. Trufanov.

1 - general view; 2 - modeling of the protome's head. 
each other, may correspond to richly decorated head-rope or to ribbons of a special loop-nauz tassel, which served not only as a decorative element of the reins, but also as an additional device for their attachment. The band of imprints, located at an angle to the two described above, can be correlated with the breast-collar (Fig. 4). In such an interpretation, the ornamental decor clearly resembles the images of richly decorated horse head harness on the contemporaneous Assyrian reliefs (8th-7th centuries BC) (Assiriya..., 2016: 155, 175, 188, 189) (Fig. 5). It should be emphasized that judging by the palace ceremonial reliefs, this type of the Middle Eastern bridle existed with both two- (Fig. 5, 1-3) and three-hole (Fig. 5, 4; Fig. 6) cheek-pieces. The latter variety, as mentioned above, has been discovered at the Novotroitskoye I settlement.

Our interpretation of the ornamental decor on the ceramic protome as a representation of the Middle Eastern bridle is supported by an interesting parallel: a ritual metal horse protome from Greece (900-700 BC) made in a geometric style (Betancourt, 1973: 213). The size of this artifact is $6.6 \times 3.2 \mathrm{~cm}$. The protome reproduces the main elements of a bridle, including the headband and the breast-collar (Fig. 7). This equipment shows a clear similarity to the bridle appearing on the relief from the palace of Ashurbanipal in Nineveh (see Fig. 5, 1,2). Richly decorated horse head harness is represented on a number of Assyrian reliefs of palace architecture (see Fig. 5, 6). Currently, the Middle Eastern tradition of decorating horse bridles, including the horse's breast-collar and other elements, is still preserved in the Maghreb countries (Fig. 8).

Several more items similar to the ceramic protome from Novotroitskoye I were found at the Strelkovskoye-2 settlement, in the Lower Angara region (Fig. 9, 10). This site is located on the right bank of the Angara River, $4 \mathrm{~km}$ northeast of the village of Strelka, in the Yeniseisky District of the Krasnoyarsk Territory (Fokin, 2004: 486; 2009: 166). Despite the fact that the attribution of the complexes from this site to specific Early Iron Age populations inhabiting the southern taiga belt of the Yenisei Siberia still requires additional argumentation (Fokin, 2016: 7), these ceramic items are quite comparable to our protome from Novotroitskoye I. Initially, they were described as a series (4 spec.) of similar tubular objects with zoomorphic images (Fokin, 2009: 166) and were correlated with the cultural layer of the Early Iron Age, containing traces of bronze casting. The radiocarbon date of $2220 \pm 105 \mathrm{BP}$ (SOAN-5486) obtained for dwelling 4, taking into

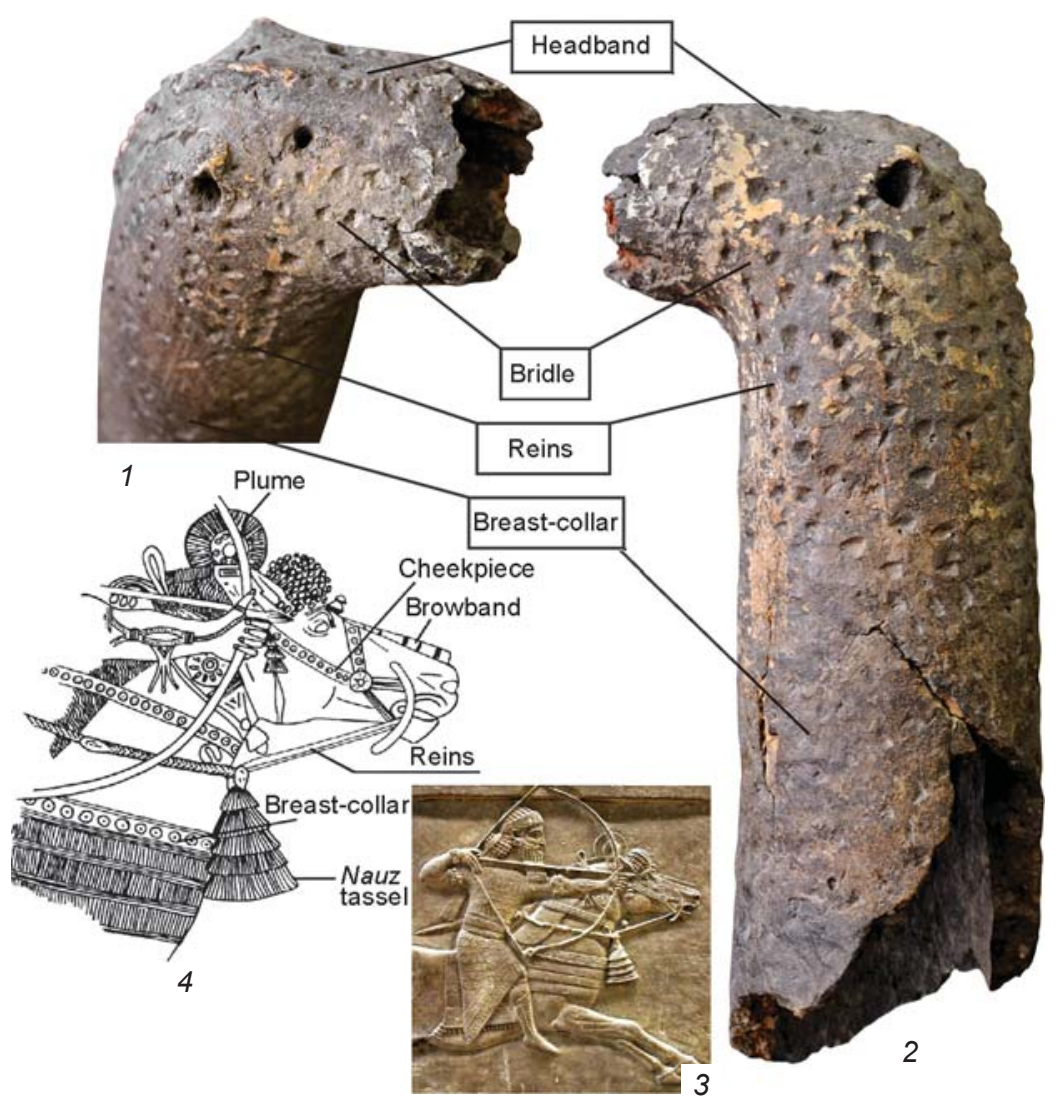

Fig. 4. Representation of bridle elements on the protome from Novotroitskoye $I(1,2)$ and on bas-relief from the palace of Ashurbanipal in Nineveh, British Museum, No. $124875(3,4)$. 
account the calibration, corresponds to a wide chronological range of 541-16 BC; although the researchers of the site have narrowed this range to the 3rd-2nd centuries BC (Ibid.). At that time, the foraging economy in the Lower Angara region was supplemented by cattle-breeding (Mandryka, 2018: 43). Nevertheless, the calibrated values of the radiocarbon date and the similarity between the ceramic items from Strelkovskoye-2 and horse protome from Novotroitskoye I suggest the possibility of giving these items the earlier date. In addition, it should be mentioned that the materials from Strelkovskoye-2 included individual artifacts from the Bronze Age (Fokin, 2009: 166). The analysis of the genesis of settlement complexes in the Lower Angara region has shown that these emerged on a local basis in the Early and Late Bronze Age (Mandryka, 2018: 30). It is equally important that cultural communities from a number of regions of Siberia, including those of Western Siberian origin, apparently participated in the cultural genesis of the southern taiga population inhabiting this region at various periods (Ibid.: 38). Therefore, we have every reason to consider the ceramic protomes from the southern taiga zone of the Middle Irtysh and Lower Angara regions in a wide temporal and cultural context as a manifestation of a certain common artistic tradition of the Late Bronze to Early Iron Ages.

\section{Results and discussion}

The exterior design of the horse protomes from Strelkovskoye-2 has the following features. The head on the surviving artifact is quite short. The ears were modeled with small protrusions (see Fig. 9). The neck is long, as in the fragment of another tubular object (see Fig. 10,2). If we ignore the artistic stylization of horse heads in Siberian artifacts, these items can be correlated with representations of horses with the so-called "swan necks", which were widespread in toreutics from the Metal Ages up to the Early Middle Ages in southwestern Siberia and the Far East. The mane on one protome was rendered by a thin notched ridge (see Fig. 10, 1). Ornamentation on all ceramic tubular items from Strelkovskoye-2 was interpreted by their discoverers exclusively in the context of their visual similarity to the decor on
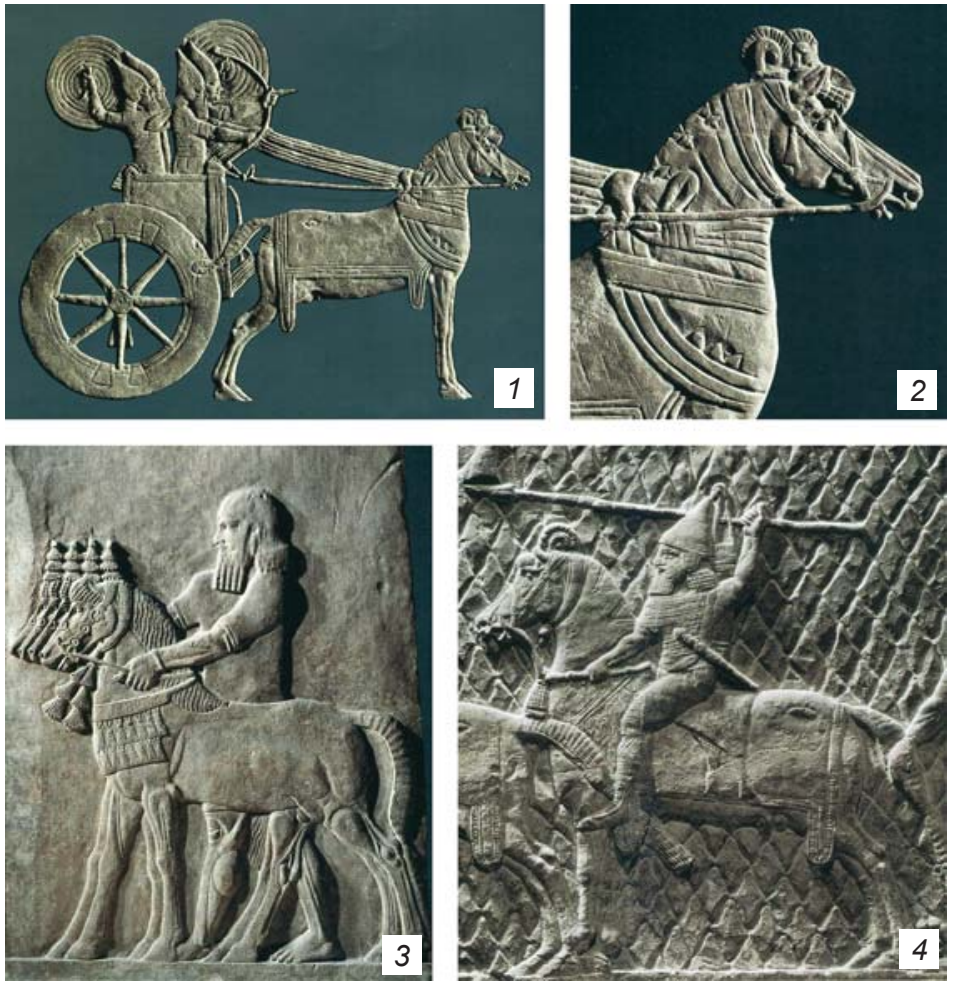

Fig. 5. Assyrian equipment of chariot horse and saddle horse (after (Assiriya..., 2016: 155, 175, 188, 189)).

1,2 - relief of a war chariot from the northern palace of Ashurbanipal in Nineveh; 3 - fragment of a bas-relief from the palace of Sargon II in Khorsabad; 4 -image of a rider from Nineveh.
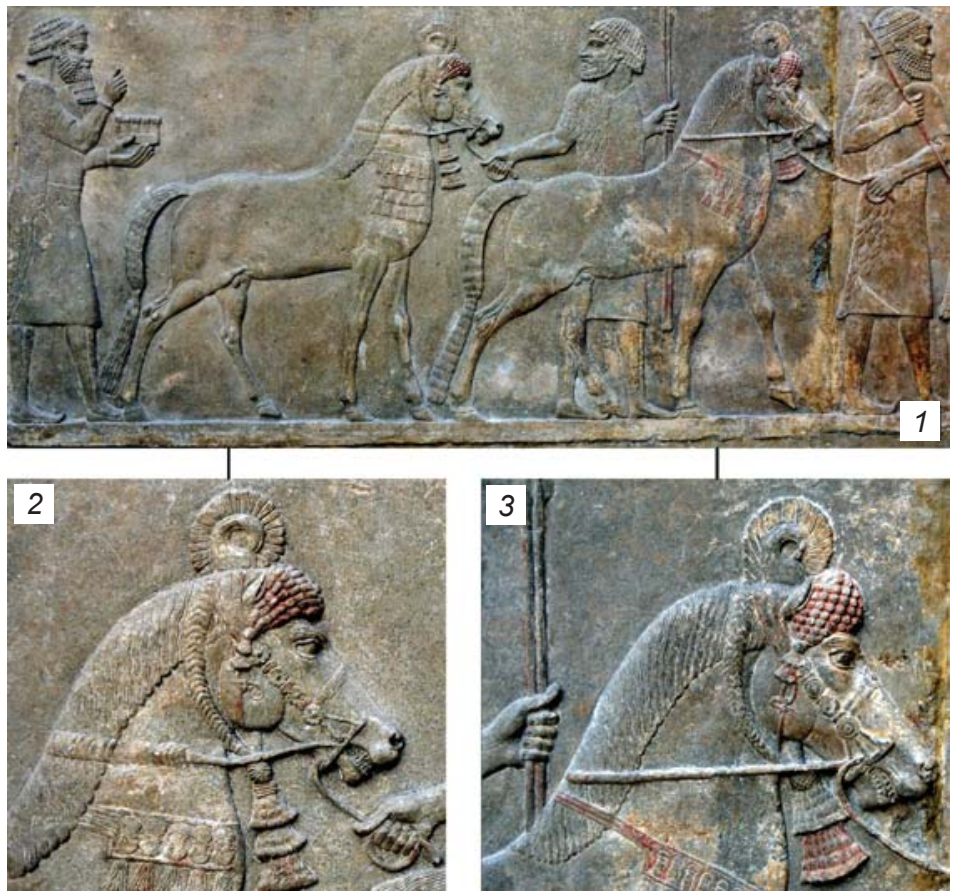

Fig. 6. Relief with horses and tributaries of Sargon II (from the palace in Khorsabad, the Louvre, Paris). Photo by A.Y. Trufanov.

1 - general view; 2,3-heads of bridled horses with three-hole cheek-pieces. 


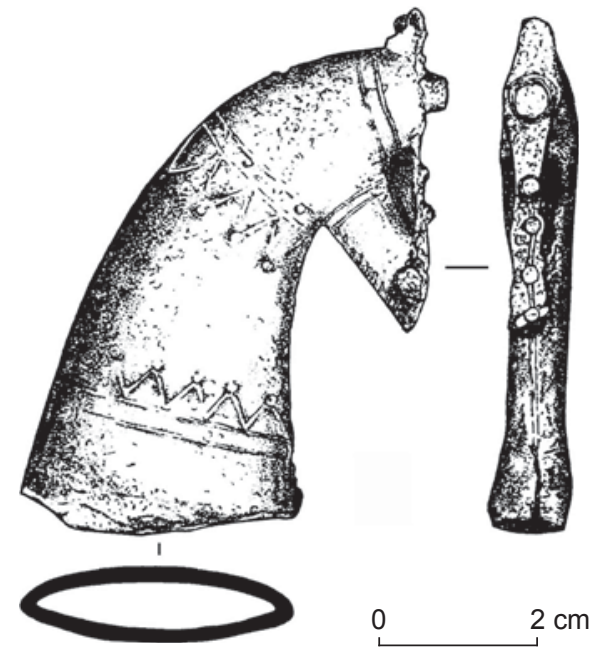

Fig. 7. Protome in geometric style from Greece, made of lead (Betancourt, 1973).

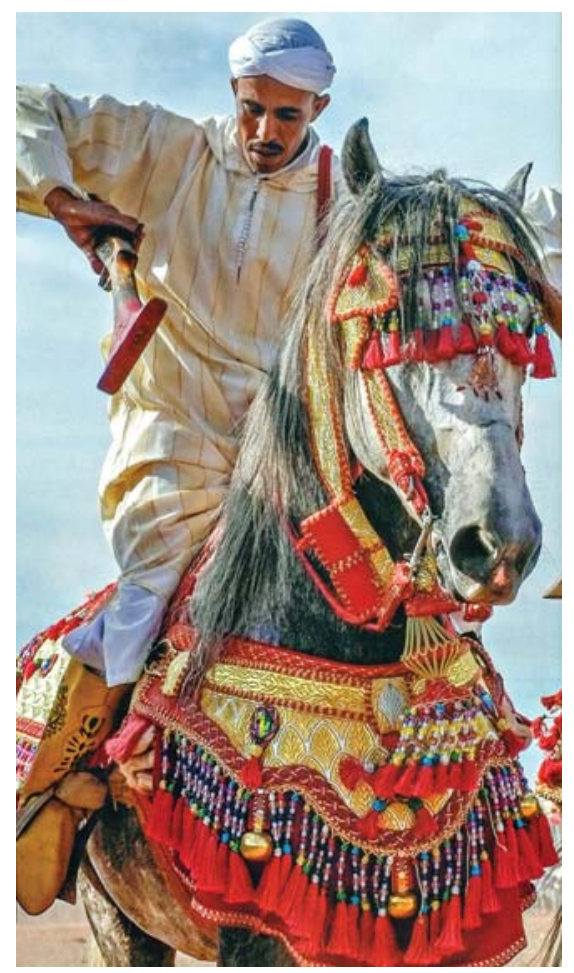

Fig. 8. Horse bridle with the breast-collar and nauz tassel (Morocco).

ceramics of the Early Iron Age (the KamenskoyeMakovskoye and Tsepan circles). Nevertheless, there is a certain compositional similarity between the arrangement of ornamentation on the protomes from Novotroitskoye I (Middle Irtysh region) and Strelkovskoye-2 (Lower Angara region); although in the latter case, the continuous decoration cannot be divided into individual elements

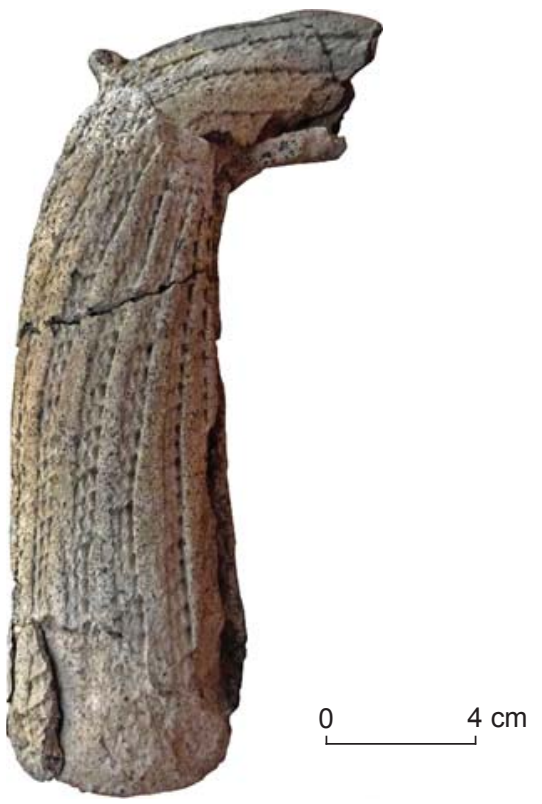

Fig. 9. Ceramic protome from Strelkovskoye-2 (Lower Angara region).
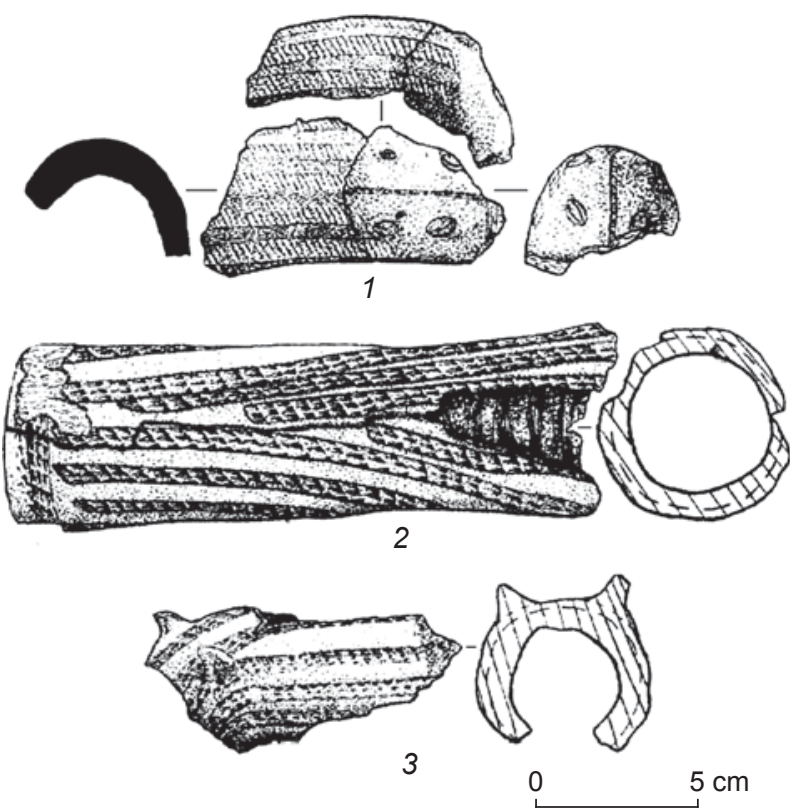

Fig. 10. Fragments of ceramic protomes from Strelkovskoye-2 (Fokin, 2009: 167, fig. 2).

of horse equipment, as it is possible to do for the item from Novotroitskoye I. The mane in the form of a notched low ridge was reproduced only on one artifact from Strelkovskoye-2 (Fokin, 2009: 167, fig. 2). Exactly this detail makes it close to the Novotroitskoye I item. Notably, despite the similarity of ceramic horse protomes from the Middle Irtysh region (Novotoritskoye I) and 
Lower Angara region (Strelkovskoye-2), they also show obvious differences. First of all, the artifact from Novotroitskoye I conveys the richest details in reflecting the features of horses' exterior appearance, and possibly of the bridle reproduced in the ornamentation. Most likely, these less clearly-expressed features preconditioned the difficulties in interpreting the image on the artifacts from Strelkovskoye-2 (Fokin, 2004, 2009).

Another issue is the purpose of the items under study. The assumption that tubular artifacts from Strelkovskoye-2 decorated the end of some stick wrapped in a bundle of straw requires a more detailed discussion. Imprints of grass on the inner surfaces of these items (Fokin, 2004) are apparently associated with the insulating layer of the blank on which the specific clay item was shaped. A similar technique was recorded on the protome from Novotroitskoye I. A certain similarity is manifested in the circumstances of discovering the protomes from the Middle Irtysh region (Novotroitskoye I) and Lower Angara region (Strelkovskoye-2). All of these were found on the territory of dwelling complexes with obvious traces of bronze-casting (splashes of bronze, fragments of crucibles and of smelting ladles). Such a context may well justify the interpretation of the cult-ritual purpose of these horse protomes. The hypothesis concerning the emergence of the horse cult in the Middle Bronze Age in the forest-steppe Ob-Irtysh region was proposed quite a long time ago (Kiryushin, 1987; Kiryushin, Grushin, 2009). In addition to this, we should also consider the paleo-economic factor. For example, in the forest-steppe Irtysh region, for the Krasnoozerka people, whose complex subsistence strategies were dominated by hunting, cattle-breeding also played a prominent role. Importantly, the protome from the Omsk region of the Irtysh (Novotroitskoye I) was discovered at a settlement located on the banks of a wide river floodplain suitable for cattle-grazing. The use of horses was crucial for such economic activity. Moreover, in the southern taiga zone of the Irtysh region, after the decline of the Andronovotype cultures of the Bronze Age in Western Siberia, cattle-breeding mostly took the form of horse-breeding (Kosarev, 1981: 229), since this specialization of animal husbandry was best adapted to local harsh climatic conditions. In addition, the presence of horse bones in the osteological samples of the Late Bronze Age in the northern territories of Western Siberia has long been considered a sign of using horses in rituals. This practice was preserved among the Khanty and Mansi up to the ethnographically modern period (Ibid.). In the material complex of the Bronze Age in the Middle Irtysh region, the attributes of ritual activities could well have included both metal pommels and ceramic protomes (Molodin, 2014: 87, Fig. 1, 2). The parallels among the materials from other, remote regions of Eurasia are not accidental, since the population of the southern taiga zone of Siberia in the Late Bronze to Early Iron Ages was involved in common cultural and historical processes on the Eurasian continent (Mandryka, 2018: 43).

\section{Conclusions}

When discussing the reasons for the emergence of ceramic horse protomes of the Late Bronze to Early Iron Ages in various southern taiga territories (Middle Irtysh and Lower Angara regions) of Siberia, a number of paleoeconomic, cultural, and historical factors should be taken into account. Starting from the first third of the first millennium BC, crucial changes took place in horsebreeding in Eurasia. First of all, horse-riding started to play an independent role, while the role of chariots significantly decreased. Second, there was a further development of horse equipment, and particularly of the elements of the bridle set. This process was reflected not only in metalworking, but also in bone-carving. Elements of bridles (bits, cheek-pieces, fittings) of that time form an innovative material complex that testifies not only to the improvement in horse-riding, but also to the rapid evolution of devices intended for this method of transportation (rein and harness design). This process is reflected in an increased general technological capacity, including the development and amplification of foundry equipment (ability to cast copper bits with one-piece mouth rings) and the process of cutting raw horn materials for manufacturing cheek-pieces, tubular beads, and headbands. Third, from the early first millennium $\mathrm{BC}$, the area of horse-breeding rapidly expanded, not only in the latitudinal, but also in the meridional direction. Certain prerequisites for this in the southern taiga zone of Siberia resulted from landscape and climate changes, and from the spread of the mixed economy in the Late Bronze to Early Iron Ages (Kosintsev, Stefanov, 1989). Ceramic horse protomes appeared there precisely in such conditions. This fact testifies primarily to the replication of these items in Eurasia in a specific archaeological period. The scale of their territorial distribution may be considered a cultural and chronological marker. The modeling of the mane is represented most clearly on the ceramic protomes described above. It differs significantly from the design appearing on stone staffs and metal pommels with horse representations from the Bronze Age, and reveals close similarities to the traditions of mane design in the Early Iron Age. No less important is the fact that the ceramic protome from the forest-steppe Irtysh region (Novotroitskoye I) belongs to a small group of artifacts on which the bridle was shown in sufficient detail. This element was reproduced extremely rarely on such items in the initial stages of the Early Iron Age. And last, if we take into account the cult purpose of ceramic protomes of the Late Bronze to Early Iron Ages from 
the Middle Irtysh and Lower Angara regions, it is quite possible to consider them as further evidence for the early integration of the horse's image into ritual practices and attributes of the population inhabiting the southern taiga zone of Siberia.

\section{Acknowledgement}

This study was performed under the R\&D Project No. 03292019-0007 of the Institute of Archaeology and Ethnography of SB RAS, "Study, Preservation, and Museumification of the Archaeological and Ethno-Cultural Heritage of Siberia".

\section{References}

\section{Abramova M.B., Stefanov V.I. 1985}

Krasnoozerskaya kultura na Irtyshe. In Arkheologicheskiye issledovaniya $v$ ranoyakh novostroyek Sibiri. Novosibirsk: Nauka, pp. 103-130.

\section{Assiriya i Vavilon: Istoriya i sokrovishcha antichnoy}

tsivilizatsii. 2016

Astana: Foliant.

Betancourt P.A. 1973

Cast lead protome from Greece. Archaeology, vol. 26 (3): 213-216.

Evraziya v skifskuyu epokhu: Radiouglerodnaya i arkheologicheskaya khronologiya. 2005

St. Petersburg: Teza.

Fokin S.M. 2004

Issledovaniya na Nizhney Angare. In Arkheologicheskiye otkrytiya 2003 goda. Moscow: Nauka, pp. 486-488.

Fokin S.M. 2009

Predvaritelniye rezultaty arkheologicheskogo izucheniya Strelkovskogo arkheologicheskogo mikrokompleksa. In Krasnoyarskiy kray: Proshloye, nastoyashcheye, budushcheye, vol. 1. Krasnoyarsk: Krasnoyar. Gos. Ped. Univ., pp. 164-168.

Fokin S.M. 2016

K probleme vydeleniya kultur rannego zheleznogo veka tayezhnoy zony Priyeniseyskoy Sibiri. Vestnik Tomskogo gosudarstvennogo universiteta. Ser.: Istoriya, No. 5 (43): 5-8.

\section{Kantorovich A.R. 2016}

Obraz loshadi v iskusstve vostochnoyevropeiskogo skifskogo zverinogo stilya. In Kavkaz i step na rubezhe epokhi pozdney bronzy i rannego zheleza: Materialy Mezhdunar. nauch. konf., posvyashch. pamyati Marii Nikolayevny Pogrebovoy. Moscow: Inst. Vostokovedeniya RAN, pp. 89-114.

\section{Kiryushin Y.F. 1987}

Noviye mogilniki ranney bronzy na Verkhney Obi. In Arkheologicheskiye issledovaniya na Altaye. Barnaul: Izd. Alt. Gos. Univ., pp. 100-125.

Kiryushin Y.F., Grushin S.P. 2009

Early and Middle Bronze Age portable art pieces from the forest-steppe zone of the Ob-Irtysh region. Archaeology, Ethnology and Anthropology of Eurasia, vol. 37 (4): 67-75.

\section{Kosarev M.F. 1981}

Bronzoviy vek Zapadnoy Sibiri. Moscow: Nauka.

\section{Kosintsev P.A., Stefanov V.I. 1989}

Osobennosti khozyaistva naseleniya lesostepnogo Zauralya $\mathrm{i}$ ishimskoy lesostepi v perekhodnoye vremya ot bronzovogo k zheleznomu veku. In Stanovleniye proizvodyashchego khozyaistva na Urale i v Zapadnoy Sibiri. Sverdlosk: UrO AN SSSR, pp. 18-27.

Kovalevskaya V.B. 1977

Kon i vsadnik: Puti i sudby. Moscow: Nauka.

Kovtun I.V. 2012

"Horse-headed" staffs and the cult of the horse head in northwestern Asia in the 2nd millennium BC. Archaeology, Ethnology and Anthropology of Eurasia, vol. 40 (4): 95-105.

Mandryka P.V. 2018

Bronzoviy i ranniy zhelezniy vek v yuzhnoy tayge srednego Eniseya i nizovyev Angary: Dr. Sc. (History) Dissertation. Barnaul.

\section{Molodin V.I. 2008}

Periodizatsiya, khronologiya i kulturnaya identifikatsiya pamyatnika Chicha (Barabinskaya lesostep). In Vremya i kultura $v$ arkheologo-etnograficheskikh issledovaniyakh drevnikh $i$ sovremennykh obshchestv Zapadnoy Sibiri i sopredelnykh territoriy: Problemy interpretatsii i konstruktsii: Materialy XIV Zap.-Sib. arkheol.-etnogr. konf. Tomsk: Izd. Tom. Gos. Univ., pp. 155-163.

\section{Molodin V.I. 2014}

Bronzovoye navershiye seiminskogo tipa s konem. In Arii stepey Evrazii. Barnaul: Izd. Alt. Gos. Univ., pp. 86-90.

\section{Molodin V.I., Parzinger G. 2009}

Khronologiya pamyatnika Chicha-1. In Chicha-gorodishche perekhodnogo ot bronzy $k$ zhelezu vremeni $v$ Barabinskoy lesostepi, vol. 3. Novosibirsk: Izd. IAET SO RAN, pp. 51-77.

\section{Schneeweiß J. 2007}

Die Siedlung Čiča in der westsibirischen Waldsteppe. Vol. I: Untersuchungen zur spätbronze- bis früheisenzeitlichen Keramik, Chronologie und kulturellen Stellung. Mainz: Verl. Philipp von Zabern. (Archäologie in Eurasien; Bd. 22).

Received April 18, 2019 Received in revised form May 28, 2019. 